\title{
Dariusz Czaja
}

Uniwersytet Jagielloński

ORCID: 0000-0001-8627-1415

$29 / 2020$

Political Dialogues

DOI: http://dx.doi.org/10.12775/DP.2020.021

\section{Nieznane arcydzieło. O Obrazach Wtoch}

\begin{abstract}
:
The Pictures of Italy by Paweł Muratow, eminent Russian writer, seems to be a book well known and unknown at the same time (with the emphasis laid on the last word). Almost a hundred years since the first Berlin edition, this totally unique book has been translated into Polish only. For a great part of Polish readers it has been recognized as an interesting and useful guide of Italy. However, this amazing book is not something like an ordinary rough guide. In my article I'm trying to mention some important and convincing reasons to treat it as history of italian art compendium, a literary masterpiece, and a historiosophy essay as well. Because of its wide ranged philosophical ambitions, it should be read along with Magic Mountain by Thomas Mann. This is a proper measure of its intellectual mastery.
\end{abstract}

Key words: Italy; journey; guide; history of art; historiosophy

Słowa kluczowe: Włochy; podróż; przewodnik; historia sztuki; historiozofia

1.

Znakomite dzieło Pawła Muratowa Obrazy Włoch jest w Polsce znane i nieznane - z naciskiem na to ostatnie. Wydana przez PIW w roku 1972 dwutomowa edycja szybko znalazła u nas entuzjastycznych czytelników. Z czasem książka stała się legendą a jej znajomość, jak sądzili niektórzy, stanowiła rodzaj jednorazowej przepustki do elitarnego klubu koneserów włoskiej kultury. Spora była w tym zasługa kongenialnego tłumaczenia Pawła Hertza. Nie będzie chyba przesadą twierdzenie, że grono zdeklarowanych miłośników dzieła rosyjskiego historyka sztuki powiększało się wyraźnie z roku na rok, potwierdzając i ugruntowując wysoką pozycję Obrazów Włoch pośród książek mających ambicję otwierania czytelnika na włoską sztukę i historię. Dla wrażliwych czytelników dzieło Muratowa rosło w czytaniu; było jak szlachetne wino, które z każdym kolejnym łykiem odsłania nowe, nie przeczuwane wcześniej, jakości smakowe. W konkurencji „podróż włoska”, książka zaczęła wyraźnie dystansować polską literaturę przedmiotu: z jednej strony, uchodzące dotąd za wzorcowe i użyteczne, acz przykurzone nieco dzieła Kremera, Klaczki, Chłędowskiego, z drugiej, ważne w swoim czasie i mające niezaprzeczalne powaby, eseistyczne tomy Iwaszkiewicza, Herberta, Karpińskiego. Bez ryzyka większego błędu, można by powiedzieć, że po dwóch dekadach od wydania polskiego tłuma- 
czenia Muratow trafił pod strzechy. Zaczął być czytany przez szerszą publiczność, jego znajomość wyszła poza kredowe koło uniwersyteckiej erudycji. Udający się do Włoch, nie bacząc na nadbagaż, zabierali do swoich walizek podróżnych dwa tomy Muratowa, ciężkie i bardzo skądinąd nieporęczne w codziennym użyciu. Z pewnością wielu z nas słyszało od powracających z włoskich wojaży solenne zapewnienia o tym, jak wiele dało im obcowanie z Obrazami Włoch, a zwłaszcza o tym, jak znakomitym przewodnikiem po włoskiej sztuce jest ich autor.

Dlaczego więc, przyznając przecież otwarcie, że księga Muratowa została u nas doceniona i stosownie wychwalona, że zdobyła wysoką pozycję pośród licznych italienisches reises, sugeruję, że jego dzieło jest u nas nieznane? Powód jest prosty, ale zasadniczy. Twierdzę bowiem, że dość powszechne traktowanie Obrazów Włoch jako swego rodzaju przewodnika - przewodnika może wyrafinowanego, kompetentnego i sprawnie napisanego, ale jednak: przewodnika - jest kompletnym nieporozumieniem. Twierdzę dalej, że ten tryb lektury nie tylko sprzeniewierza się zasadniczej intencji tekstu, ale całkowicie zapoznaje to, co jest esencją tego porywającego i dziś arcydzieła. Polska recepcja książki Muratowa (oczywiście, mówię tu o pewnym „uśrednionym” odbiorze - generalizującym i pewnie niesprawiedliwym) to kliniczny wręcz przykład misreading, w najszerszym możliwym zakresie tego wieloznacznego terminu. A więc rozumianego tu jako: złe odczytanie, mylne odczytanie, niedoczytanie, nieodczytanie... Oznacza to - najogólniej rzecz ujmując - że lektura Obrazów Włoch idąca po tropach „turystyczno-krajoznawczych" nie tylko boleśnie okroiła tę książkę z głębokiego antropologicznego i historiozoficznego programu, ale że - stosując strategię stwarzania „na obraz i podobieństwo” - znacząco uprościło i pomniejszyło znaczenie jej duchowego przekazu.

$\mathrm{Na}$ kontrze do tej, dość rozpowszechnionej, lektury dzieła rosyjskiego historyka sztuki twierdzę, co następuje: po pierwsze, Paweł Muratow w żaden sposób nie przypomina wypakowanego po sufit erudycją ambitnego przewodnika po włoskiej krainie; po drugie, umieszczenie jego Obrazów Włoch na półce z przewodnikami jest nie tylko bolesnym sprzeniewierzeniem się zasadniczej idei jego dzieła, ale także drastycznym spłaszczeniem myśli w nim zawartych. W dalszej części szkicu spróbuję podać racje stojące za takimi supozycjami.

Zanim jednak zajmiemy się detalicznie książką, na początek dwa słowa o formacie intelektualnym Muratowa, jako że skala niewiedzy na jego temat dorównuje bodaj osobliwej recepcji jego wielkiego dzieła. Dotyczy to zresztą nie tylko polskiego czytelnika, który i tak jest w wyjątkowo komfortowej, by nie rzec - uprzywilejowanej sytuacji. W świecie zachodnim wiedza o znakomitym rosyjskim historyku sztuki (autorze książek o ikonie ruskiej i Fra Angelico) i pisarzu (powieść Egeria) jest śladowa, a znajomość jego głównego dzieła w świecie zachodnim - żadna. Trudno się nawet dziwić: brak przekładów jego Obrazów na angielski, francuski czy niemiecki czyni z niego postać widmową. Jedynym jak dotąd - rzecz prawie nie do uwierzenia - tłumaczeniem rosyjskiego oryginału jest polska edycja! I jest to właśnie przekład wspomnianego Pawła Hertza. 
Przekład twórczy, językowo zniuansowany, miejscami hipnotyzujący. Uważnego i empatycznego czytelnika polskiej edycji nie dziwi zapewne zdanie tłumacza, skądinąd znanego z ogromnej powściągliwości, który wyznał kiedyś: „to najstaranniej i najpiękniej przetłumaczona przeze mnie książka”. Ta czułość dla ducha i litery oryginału przenika niemal każde zdanie polskiego przekładu.

Jak wspomniałem, w językach zachodnich Obrazy Włoch nie istnieją i tylko nieliczni pojmują wagę i znaczenie tej nieobecności. Kilka lat temu ukazał się opasły tom, zatytułowany Cultural Amnesia, autorstwa Clive’a Jamesa, wybitnego brytyjskiego dziennikarza i eseisty. ${ }^{2}$ Ta wielka księga, której napisanie zabrało mu prawie czterdzieści lat, jest w gruncie rzeczy - opowiedzianą poprzez krótkie, parustronicowe hasła - próbą nakreślenia nowej mapy pamięci. Nowej, bo uwzględniającej to, co ze współczesnego myślenia wyparte, usunięte, albo z tych czy innych powodów zapomniane. James przedstawia $\mathrm{w}$ porządku alfabetycznym ponad sto sylwetek postaci, które według niego z tych czy innych względów popadły w zapomnienie, a które warto przypomnieć, bo są istotne dla zrozumienia złożonej natury naszej współczesności. Rozpoczyna od A (jak Achmatowa) a kończy na Z (jak Zweig). W tym, powiedzieć trzeba, dość egzotycznym ogrodzie (pośród wybranych przezeń postaci znalazł się filozof Wittgenstein i muzyk Duke Ellington, fizyk Einstein i pisarz Zinowiew), przy literze M - po charakterystyce poezji Miłosza i Montalego - pojawia się znienacka postać Pawła Muratowa. Znać po tonie wypowiedzi i wyraźnej afektacji, że to niespodziewane odkrycie rosyjskiego pisarza i jego znakomitego dzieła było dla Jamesa wydarzeniem wielkiej wagi. Dość powiedzieć, że specjalnie nauczył się rosyjskiego, by móc przeczytać Obrazy Włoch, książkę, wedle niego, absolutnie cudowną, która - odwrotnie do swojej ponadczasowej wartości - została w świecie zachodnim kompletnie zapomniana.

Biogram Muratowa, to $\mathrm{w}$ istocie ekstatyczna (acz podbudowana racjonalnymi argumentami) laudacja na cześć jego włoskiej księgi. „W świecie istnieje wiele nieznanych arcydzieł, lecz zwykle popadają w ten stan dlatego, że naprawdę nie są to utwory zbyt wysokich lotów. Obrazy Włoch - to prawdziwe nieznane arcydzieło". ${ }^{3}$ Przywołując w swoich uwagach aluzyjnie, acz czytelnie tytuł sławnej noweli Balzaka, Le chef d’oeuvre inconnu, James daje do zrozumienia, że doskonale zdaje sobie sprawę, z jaką klasą dzieła ma do czynienia. Umieszczając księgę Muratowa na szerokim tle gatunku „podróży włoskiej” stwierdza, że żadna książka z tej dziedziny nie wytrzymuje porównania z Obrazami Włoch. Powtarzam: żadna! Dzieło Muratowa, stwierdza jednoznacznie i autorytatywnie, jest lepsze od - wybitnych w swojej klasie - dzieł Goethego, Gregoroviusa, Burckhardta, czy Symonsa: „Lepsze od Goethego? Tak, lepsze od Goethego. Muratow odwiedził wszystkie te miasta i miasteczka, wiedział wszystko o sztuce i literaturze, miał

1 P. Hertz, Gra tego świata, Warszawa 1997, s. 392.

2 C. James, Cultural Amnesia. Necessary Memories from History and the Arts, New York-London 2007.

3 Tamże, s. 527. 
stanowcze przekonania i cały ten kompleks myślowego i fizycznego doświadczenia zmieścił w skondensowanych, przejrzystych paragrafach, przesyconych znaczeniem i wrażliwością. Książka jest po prostu zbyt dobra, by jej istnienie było prawdą. Zanim ktokolwiek przetłumaczy ją na w miarę porządny angielski, jej entuzjasta będzie zawsze narażony na ryzyko, że ją sobie wymyślił. Ale ona istnieje naprawdę". James pojął dość szybko, że w książce Muratowa chodzi o coś dużo głębszego niż o zwiedzanie włoskich miast, podziw dla włoskiej sztuki, czy wyrafinowany smak podróżowania. Zobaczył w niej znakomity literacko tekst, dzieło pisarza dużej miary, ale także - a może przede wszystkim! - rzecz o duchowym spoiwie przenikającym dzieła sztuki, pejzaże, miasta.

Myliłby się ten, kto by sądził, że afektacja Jamesa dla dzieła Muratowa jest nadmierna, a jego podziw dla wielkości Muratowa nieco histeryczny i całkiem odosobniony. Kto uważnie przeczytał Obrazy Włoch i nie zatrzymał się na powierzchni opisywanych obrazów i zdarzeń, nie miał nigdy w tej materii żadnych wątpliwości. Josif Brodski, zagadnięty kiedyś na nowojorskim uniwersytecie o postać rosyjskiego historyka sztuki, odpowiedział prosto i z wyraźnym przejęciem: „Ah! He was a genius!”5 Bezsprzecznie, był Muratow człowiekiem wielkiego formatu, a jego klasę intelektualną, niepoczytalną erudycję i nadzwyczajną wrażliwość podkreślali wszyscy co inteligentniejsi jego znajomi. W świetnych zapiskach Niny Berberovej, rosyjskiej pisarki i jak Muratow emigrantki, czytamy o ich wspólnym berlińskim epizodzie z lat 20. ubiegłego wieku: „Anemiczne Niemcy, anemiczne pieniądze, anemiczne krzewy Tiergartenu, gdzie czasem rankiem spacerowaliśmy z Muratowem. W przeciwieństwie do Biełego był człowiekiem ciszy, rozumiejącym burze i człowiekiem wewnętrznego ładu - rozumiejącym wewnętrzny bezwład innych. (...) Był zawsze zakochany w swoim zaciszu i owo uczucie też było nieco stylizowane - czasem na cierpienie, czasem na radość. Jego oczarowania i rozczarowania były natury bardziej intelektualnej niż zmysłowej. Był jednak człowiekiem zmysłowym, a nie tylko 'mądrym duchem'. Był hojny, obdarzał rozmówcę myślami, które inny na jego miejscu zapisywałby sobie w notesiku (...), on zaś wypuszczał jej niczym gołębie z klatki, żeby je mógł schwytać każdy, kto zechce. Część z tych myśli wciąż we mnie trwa. Nie znosił jednak uznania i wdzięczności, a w sobie i w innych lubił tylko wolność. Był pozbawionym wszelkich pęknięć okcydentalistą, który jeszcze przed pierwszą wojną światową odkrył dla siebie Europę, ja zaś owego roku poznawałam ją za jego pośrednictwem”. ${ }^{6}$ Berberova miała szczęście zwiedzać Rzym z Muratowem a hipnotyczna aura tych rzymskich peregrynacji zostały w niej przez lata: „Być w Rzymie. Mieć za przewodnika Muratowa. Dziś wydaje się to czymś fantastycznym, niczym sen, z którego człowiek przez trzy dni nie może się otrząsnąć. Była to jednak realność, mój najzwyczajniejszy los w Rzymie. Widzę siebie obok Mojżesza Michała Anioła, przy niewysokim, milczą-

4 Tamże.

${ }^{5}$ W. Karpiński, Promieniowanie Muratowa, „Zeszyty Literackie” nr 106.

${ }^{6}$ N. Berberova, Podkreślenia moje. Autobiografia, przeł. E. Siemaszkiewicz, Warszawa 1998, s. 191-192. 
cym mężczyźnie i znów idę z nim na długi spacer Trastevere, gdzie wstępujemy na stare podwórka, które zna tak, jakby się tutaj urodził. Stoimy obok jakiejś anonimowej płaskorzeźby i przyglądamy się jej równie uważnie jak fresk Rafaela. Włóczymy się po via Appia, wśród grobowców, wieczorem siadujemy w kawiarni przy Piazza Navona i jemy obiad w restauracji di Trevi"?

W tym szybkim reporterskim fleszu uchwycona została nadzwyczajna chłonność, może nawet: zachłanność Muratowa. Tak, on naprawdę chciał zobaczyć wszystko i doświadczyć wszystkiego, co włoskie, na każdym poziomie i we wszystkich rejestrach: miał słuch nie tylko na wielką sztukę, ale i atencję dla mniej znanych dzieł, cieszył go zapach starych kamienic, ale i smak wina w przydrożnej knajpie. To wszystko miało się kiedyś złożyć na wielką syntezę południowego świata zawartą w Obrazach Włoch....

\section{2.}

Nie mam (i nigdy nie miałem) cienia wątpliwości, że przedstawiona przez Jamesa ocena dzieła Muratowa jest odpowiedzialna i trafna. Wspomnianą przez niego siłę rażenia Obrazów Włoch, ich nieprzemijające duchowe oddziaływanie, można i dzisiaj odczuć. Ale prywatne, choćby najbardziej autentyczne afekty to - zdaję sobie sprawę - dość słaby argument w sprawie. Spróbujmy więc zobiektywizować powyższe mniemanie. A zatem: na czym polega wielkość Muratowa i co to bliżej znaczy, że jego dzieło nie jest przewodnikiem, że nie sposób go uznać za wyrafinowany bedeker dla kulturalnych elit? Żeby odpowiedzieć na to pytanie, trzeba wejść pod skórę tekstu. Inaczej mówiąc: trzeba przejść od warstwy powierzchniowej książki, od tego, co wyrażone wprost, w stronę myślowego rusztowania na którym oparta jest cała narracja, do treści implikowanych w tekście.

Czym więc, najogólniej rzecz biorąc, są Obrazy Włoch? To może najpierw przenikliwy portret świata włoskiej historii, sztuki i architektury. Portret empatyczny i wielostronny, w którym znalazło się miejsce na fachowy wykład, subiektywne spojrzenie i ideowy program. To rozpisana na szereg mikroopowieści anatomiczna lektura pewnej lokalnej postaci kultury europejskiej. Wszakże waga tego, co zwykliśmy nazywać „włoskim doświadczeniem”, wedle Muratowa polega na tym, że to doświadczenie powinno się stać naszym udziałem, że nie ogranicza się tylko do lokalnego wymiaru. Naszym, a więc wszystkich tych, Włochów i nie-Włochów, którzy myślą o Europie nie w kategoriach geograficznych, ale cywilizacyjnych i duchowych. Chce nas przekonać nie tylko o tym, że włoska sztuka i włoski pejzaż zasługują na wyjątkową uwagę (to bowiem czyni, lepiej czy gorzej, każdy bedeker), ale chce nam uświadomić także ich znaczenie dla europejskiego myślenia: zarówno o przeszłości (co dość oczywiste), ale także o kształcie przyszłości (co już dużo mniej oczywiste). Taka jest najogólniejsza rama ideowa jego wielowątkowej narracji.

7 Tamże, s. 238. 
Zejdźmy jednak na ziemię. Księga Muratowa - obojętnie jak ją oceniać - jest nade wszystko t e k s t e m . Jest „obiektem” ze słów uczynionym, podpada więc pod wszystkie kategorie, stosowane zwyczajowo do opisu jakiejkolwiek narracji. Zastanówmy się przez chwilę nad językiem tego dzieła, językiem szczególnym. Uważny opis języka Obrazów Włoch wiele mówi nie tylko o jego stronie formalnej, ale - jak postaram się wykazać - bezpośrednio dotyka tego, co zwykliśmy nazywać zwyczajowo „treścią” tekstu. Twierdzę bowiem, że te dwa elementy: „formę” i „treść” da się rozdzielić tylko sztucznie, w analitycznym rozbiorze. U Muratowa „forma” w jakiś sensie je s t „treścią”, w każdym razie z pewnością nie jest przezroczystym semantycznie wehikułem dla wykładanych „treści”. Inaczej mówiąc: językowa opowieść Muratowa nie jest przezroczysta i semantycznie „niewinna”.

Powiada się zazwyczaj, że Muratow jest wybornym stylistą, że używa słów z dużą precyzją i z dużą świadomością ich wagi i znaczenia. Ale sprowadzając jego opowieść tylko do wymiaru estetycznego niewiele z niej pojmiemy. Przyjrzyjmy się teraz detalicznie elementom konstytutywnym językowej konstrukcji Obrazów Włoch. Wspiera się ona na kilku solidnych przęsłach: sensualności, typizacji, oraz mityzacji opisywanej rzeczywistości.

Pierwsza z wymienionych cech jest dość łatwo uchwytna, narzuca się czytelnikowi Muratowa niemal od pierwszej strony. Przykładów obrazujących tę właściwość jego tekstu znajdziemy w książce aż nadto: w wypełniających jego dzieło ekfrazach, w przenikliwych opisach przestrzeni miejskiej. Dla unaocznienia tej tezy przewrotnie nieco wybieram opis pejzażu. Oto fragment z umbryjskiej podróży, jeden z licznych należących do długiej „sensualnej” serii: „Powietrze, prawdziwy żywioł Umbrii, jej łagodne bóstwo, nigdy nie bywa słodsze niż w te pierwsze wiosenne dni. Znad cichych wód w dolinach, znad źródeł, nad którymi stoją lub stały świątynie, znad powoli płynących rzek i spadających z gór potoków unoszą się lekkie mgły. Rankiem jasne, lśniące obłoki suną nad doliną, strącając niewidoczne krople rosy na czuby topoli, w których pulsują młode, krzepkie soki. Około południa słońce osusza wilgoć, ale nad błękitnymi lililiowymi krawędziami gór wciąż gromadzą się obłoki. Poniżej lśniących śniegów, szaleją burze, a echo donosi odgłos dalekich grzmotów. Wszyscy chłopi, którzy obcinają pędy łóz spowijających drzewa, zwracają uwagę w tę stronę. W takiej chwili nad doliną Umbrii płynie nieświadoma modlitwa do sił przyrody i potężnej dłoni, która nimi włada"8.

Fotograficzne oko, subtelność opisu, wrażliwość kolorystyczna - wszystko to sprawia, że opisywany fragment zdaje się - podkreślam - z d a je s i ę nam niesłychanie bliski, niemal dotykalny, czytelnik ma poczucie, że „owiewa” go umbryjskie powietrze i gotów by przysiąc, że „czuje” na swojej skórze poranną rosę. Język Muratowa ma niebywałą zupełnie zdolność ewokowania widzianego i przeżywanego świata, jego zmysłowego miąższu. Doskonale wie on, jak uzyskać barthesowski l'effet de réel, czyli sprawić, by

${ }^{8}$ Muratow, Obrazy Włoch, przeł. P. Hertz, t. 2, s. 112. 
czytelnik wszedł bez trudu w opisywany świat i uwierzył w jego pozatekstową realność. Ta właściwość jego języka niezwykle przypomina założenia „sensytywizmu” Lodewijka van Deyssela, holenderskiego pisarza, krytyka i teoretyka literatury, który pod koniec XIX stulecia wprowadził do instrumentarium humanistycznego pojęcie „doznania”, kategorii różnej od „obserwacji” i „wrażenia”. Według niego literatura powinna dostarczać nam nie tylko wiarygodnej i „realistycznej” obserwacji społecznego świata, ale winna raczej - jak komentuje założenia sensytywizmu Frank Ankersmit - „starać się dostarczyć czytelnikowi powieści tego, co można by nazwać 'odczuciem i dotknięciem rzeczywistości’ (...) z wszystkimi konotacjami postrzeżenia zmysłowego, jakie łączą się z tym pojęciem". Ankersmit wykazuje odkrywczo, jak wielką rolę odegrały te idee w koncepcji „doznania historycznego” Johana Huizingi, jak mocno wpłynęły one na bardzo rozpoznawalny, sensualny właśnie, niezwykle plastyczny styl jego narracji historycznych. Nie sugeruję tu oczywiście żadnych wpływów i zależności, chcę tylko przy tej okazji mocno podkreślić ów szczególny, przyliteracki, „powieściowy” charakter języka Muratowa. Efekt, który Huizinga osiągał w odniesieniu do przeszłości historycznej, Muratow uzyskiwał w odniesieniu do obrazów, dzieł architektury i krajobrazu. W obydwu przypadkach czytelnik odnosi wrażenie żywego uczestnictwa w opowiadanych zdarzeniach, albo opisywanej rzeczywistości. Retoryka Huzingi Muratowa ma nie tylko moc ewokowania „świata przedstawionego", ale też magiczną moc teleportowania czytelnika wprost do jego wnętrza.

Rekonstruuję cechy języka Muratowa nie po to, by zaraz zdekonspirować jego dzieło. By go zdemityzować, słowem, żeby wykazać, że stanowi ono zaledwie słowną reprezentację bez żadnej referencji do opisywanej rzeczywistości. Albo, by w odczarowującym geście deziluzji odsłonić jego retoryczne rusztowanie, odkryć „jak-to-zostało-zrobione” i tym samym unieszkodliwić wartości artystyczne i poznawcze tekstu. Owszem, zależało mi na tym, by pokazać, jak rosyjskiego pisarz k o n s t r u u j e przy pomocy języka postrzeganą przez siebie rzeczywistość, ale jednocześnie, by zwrócić uwagę na to, że językowa konstrukcja nie tylko nie przesłania jej sobą, ale bywa, że w ogóle umożliwia nam widzenie. Inaczej mówiąc, że język nie jest tu tylko zasłoną, przegrodą - jak głosi poststrukturalistyczna mantra - ale, że czasem ma także zdolności ujawniania stron rzeczywistości skrytych przed potocznym spojrzeniem. Że jest narzędziem rewelacji, odsłonięcia istotnego.

Ciekawym, bo niejednoznacznym, składnikiem włoskiej opowieści Muratowa jest typizacja. Pojawia się ona w opisie przedstawicieli jakiegoś regionu, prowincji, czy miasta. Stosuje ten zabieg dosyć często i nie mam pewności, czy miał on świadomość konsekwencji poznawczych, które tego rodzaju strategia ze sobą niesie. To jest ta właściwość jego tekstu, która - powierzchownie rzecz ujmując - mogła by zbliżać konstatacje $\mathrm{Mu}$ ratowa do przewodnikowych narracji. Spójrzmy na taki fragment: „Brak opanowania,

9 F. Ankersmit, Język a doświadczenie historyczne, przeł. S. Sikora, „Konteksty” nr 1-2:1997, s. 82. 
z którego niestety słynie Pistoia, stanowi chyba nie tyle wrodzoną cechę mieszkańców miasteczka, co ludności górzystych okolic, które pozostają w zasięgu jej władzy. Pistoia leży tuż u wejścia do wąwozów, wiodących przez Apeniny ku Parmie i Bolonii. Ku niej ciąży cała rozległa kraina pogórza toskańskiego. Tam, na skalistych urwiskach i w wąskich dolinach rzek, na pół dzika szlachta, właściciele podgórskich obszarów prowadzili z sobą okrutną wojnę podjazdową, na którą składały się zasadzki, nocne zajazdy i skrytobójstwa. Wyrastały tu pokolenia chłopów i pasterzy, którzy na odgłos dzwonu z parafialnego kościoła zawsze byli skłonni zamienić rydel i kij na arkebuzę lub topór o dwu ostrzach". ${ }^{10}$

Zwraca uwagę wielki kwantyfikator stosowany przez autora. W wyniku tej operacji okazuje się, że każdy (bez wyjątku!) mieszkaniec Pistoi i okolic staje się człowiekiem o krewkim temperamencie. Trzeba przyjąć na wiarę konstatacje autora, bo nie sposób ich wiarygodności sprawdzić. Uśredniając różnorodność mieszkańców Pistoi, sprowadzając ich do wspólnego mianownika nadaje on obserwowanej rzeczywistości cechy spójności i jednorodności, których - można zasadnie sądzić - opisywana rzeczywistość raczej nie posiadała. Można by bronić Muratowa, utrzymując, że chodzi mu może raczej o pewien typ idealny, niż indukcyjne uogólnienie, ale podejrzenie, że „obchodzi” on rzeczywistość przy pomocy jednoznacznych porządkujących etykiet, dalej pozostaje w mocy. Gorzej, bo taka praktyka przypomina jako żywo zabiegi stosowane przez autorów popularnych przewodników. W odniesieniu do Guide Bleu, sławnego francuskiego bedekera, tak pisał o tym procederze Roland Barthes: „Dla Niebieskiego przewodnika ludzie istnieją tylko jako 'typy’. Na przykład w Hiszpanii Bask jest marynarzem lubiącym przygody, Katalończyk - sprytnym handlarzem, a Kantabryjczyk - sentymentalnym góralem". ${ }^{11}$ Rzeczywiście, w tym przypadku podobieństwo uwag Muratowa do symplifikujących konstatacji przewodnika narzuca się samo i nie ma powodu, by tę okoliczność prześlepiać.

Ale równocześnie, trzeba zaraz dodać, w narracji Muratowa jest także coś - i to coś istotnego - co różni typizację przewodnikową od jego uogólnień, rzeczywiście czasem bezkrytycznych i nieco naiwnych. I widać to nawet w cytowanym wyżej fragmencie. Mówiąc najkrócej: typizacje przewodnikowe są całkiem oderwane od rzeczywistości, to wydmuszki, peirce’owskie znaki indeksowe, tyle że puste w środku, natomiast w typizacjach Muratowa zawsze mocno obecny jest kontekst kulturowy i historyczny. Jego uogólnienia nie zawsze trafne, może czasem przesadzone - mają zwykle w tle empiryczny konkret. I to jest coś, co radykalnie odróżnia obydwa wyszczególnione sposoby typizacji. Muratow zawsze podaje racje, które stoją za jakiego ustaleniami. Jeszcze lepiej tę różnicę widać wtedy, kiedy Barthes pokazuje sposób, w jaki funkcjonują w przewodniku wychwalane przy pomocy gwiazdek „Zabytki”: „Wybierając zabytki, odbiera się realność zarazem ziemi i ludziom, w ogóle nie oddając teraźniejszości historii, przez co i sam zabytek staje się

${ }^{10}$ Muratow, dz. cyt., s. 244, t.1

11 R. Barthes, Mitologie, przeł. A. Dziadek, Warszawa 2000, s. 158. 
nieczytelny, więc niedorzeczny". ${ }^{2}$ W Obrazach Włoch jest dokładnie odwrotnie. Opisując kościół, zamek, ogród, czy ruiny Muratow daje nie tylko fachowy opis tego co widzi, ale zawsze umieszcza omawiany obiekt w kontekście historycznym, odsłania maksymalnie dokładnie realne tło - ideowe, społeczne, estetyczne - w ramach którego został on powołany do życia. Pokazuje nici, które łączą widziany w „naszej” teraźniejszości tak zwany „zabytek” z czasem minionym. Jeśli dla Barthesa przewodnik Guide Bleu w ostatecznym rachunku staje się narzędziem ogłupiania, to na kontrze do tego, powiedzieć można zasadnie, że przy pewnych słabościach i - dostrzeganych z dzisiejszej perspektywy - anachronizmach, Obrazy Włoch są raczej instrumentem oświecenia.

I jeszcze zabieg mityzacji - tak wyraźnie obecny we włoskiej opowieści Muratowa. Długo nie rozumiałem na czym polega szczególny czar, który rzuca ta książka na czytelnika. Wydaje mi się, że jesteśmy blisko wydobycia jego istoty, kiedy uświadomimy sobie, że Muratow tworzy w istocie w swoich opisach świat pozaczasowy. Ma on, rzecz jasna, doskonały zmysł historyczny, świetnie wie, że opisuje świat zanurzony w żywej i zmiennej historii, ale pod jego piórem dziejowa płynność nabiera ontologicznej statyczności. Przyjmuje kształt skończony, ostateczny i niezmienny - obserwujemy go trochę jak owada zatopionego w bursztynie. To chwila przemieniona $\mathrm{w}$ wieczne teraz. Jeden tylko przykład, ale doskonale odsłaniający mityzacyjną praktykę rosyjskiego autora: „Vicenza, której zbite w gromadę czerwone dachy widnieją wśród zielonych ogrodów i winnic szczęśliwej doliny dzieląc podnóże Alp od Wzgórz Monti Berici, pojawia się we wspomnieniach jako jedno z najbardziej uroczych miast włoskich. Dwie nieruchome zwierciadlane rzeczki, Retrone i Bacchiglione, opływają miasto, którego ulice wychodzą gdzieniegdzie na ciągnące się wzdłuż brzegów łąki, a łuki przerzuconych nad nimi mostów odbijają się w głębokim lustrze ich wód. Słońce, które upodobało sobie to piękne miasto, obficie zlewa swój blask i ciepło na płyty jego wspaniałego Piazza, gdzie widnieją białe jak śnieg istryjskie marmury bazyliki Palladia z czerniejącymi na jej kolumnach i fryzach śladami zimowej niepogody. Podróżny, olśniony widokiem tego cudu architektury, wobec którego blednie nawet wenecka Libreria, długo stoi na placu pogrążonym w uroczystej ciszy rzeczy doskonałych i jak we śnie chodzi po pustych, fantastycznych ulicach, wzdłuż cichych warsztatów dzisiejszych rzemieślników i wspaniałych siedzib renesansowych". ${ }^{13}$

To nie jest przecież zwykły reporterski zapis, to nie jest opis jakiejś konkretnej chwili, którą da się zaznaczyć w kalendarzu. Muratow daje nam coś w rodzaju fenomenologicznego oglądu ejdetycznego, przedstawia swego rodzaju stereometryczną syntezę swojego widzenia. Przy pomocy językowych środków zawiesza oglądane „tu i teraz” miasto w aurze bezczasu odpornej na chronologię. Tego rodzaju zabiegi sprawiają, że wbrew zwyczajowej lekturze, Obrazy Włoch nie są tylko r e a l i s t y c z n ą fotografią włoskiego

12 Tamże, s. 159.

${ }_{13}$ Muratow, dz.cyt., t. 2, s. 326. 
świata. Inicjalnie są, owszem, próbą zapisu realistycznej powłoki świata w jego zmysłowym miąższu. Ale już chwile później opis zmierza w inną stronę: spojrzenie pisarza nie zatrzymuje się na rejestracji „powierzchni” rzeczy, ale stara się ujawnić jej głębsze warstwy nie dające się już zmierzyć miarami historii sztuki, czy urbanistyczno-geograficznej erudycji. W pisarstwie Muratowa tkwi esencjalne pragnienie oddania - niewidocznej, niewidzialnej w potocznym spojrzeniu - duchowej aury rzeczywistości. Bo w jego rozumieniu świat doświadczany zmysłami rozszczepia się na dwie sfery: widzialnego i niewidzialnego. Dlatego tak bardzo mylą się ci, którzy czytają je w duchu, właściwego przewodnikom, naiwnego realizmu (styl, nurt, autor, data). Wydaje się wielce prawdopodobne, że w wielu narracjach Muratowa odezwały się jego inklinacje symbolistyczne z właściwą temu ruchowi strategią „podwójnej” lektury rzeczywistości zmysłowej. Był to, dodajmy jednak od razu, symbolizm szczególny, nie pokrywający się z jego literackim odpowiednikiem w wersji praktykowanej przez rosyjskich poetów (np. Biełego). Berberova tak o tym pisze: „Był po swojemu symbolistą, z jego kultem wiecznej kobiecości, a zarazem nie był podobny do nikogo ze współczesnych. Symbolizm jego stanowił raczej rodzaj otaczającej go aury, w której zarówno jemu, jak i ludziom z jego otoczenia lekko się oddychało. Nie był to symbolizm mglisty, lecz przejrzysty, symbolizm nie dekadencki, lecz sub specie aeternitatis". ${ }^{14}$

Księga Muratowa to w swojej warstwie istotnej czystej wody narracja mityczna. Użyty tu przymiotnik „mityczny” uwolnić trzeba od razu od potocznych, czy publicystycznych konotacji. Nie oznacza on bowiem prostackiego kłamstwa, nieprawdy czy zmyślenia, ale wskazuje na szczególny rys tej zachwycającej opowieści. Nazwanie relacji Muratowa „mityczną" nie oznacza, że autor łże, że daje opisy tego, co poznał „z drugiej ręki”, albo, że zgoła nigdy nie widział na własne oczy obiektów swoich fascynacji. Oznacza, mówiąc najkrócej, że jego narracja nie jest - i nie miała być w autorskim zamierzeniu - fotograficznym, indeksalnym, przewodnikowym, czy kronikarskim zapisem świata, ale że dotyczy rzeczywistości oczyszczonej z akcydensów i sprowadzona zostaje do jej esencjalnej postaci. Jak archaiczny mit, w kształcie znanym z rozpraw religioznawców, mówi ona o rzeczywistości mocnej, trwałej, życiodajnej, rzeczywistości, która staje się modelem do naśladowania.

Tak rozumiane Obrazy Włoch przestają być dokumentalną rejestracją włoskiej rzeczywistości, ale stają się prawdziwą księgą mityczną, bliską w swej konstrukcji i oddziaływaniu mitologii archaicznej. To oczywiście mit uwolniony od sankcji sakralnych, ale zachowujący wciąż istotne jego elementy. Czytamy u van der Leeuwa: „Mit nie jest właściwie niczym innym jak słowem. N i e je s t s p e k u la c ją ani poematem, prymitywną interpretacją świata ani filozofią w zarodku (jakkolwiek może być i niekiedy jest tym wszystkim). Jest słowem mówionym, które, powtarzane, posiada moc rozstrzygającą. (...) Mit nie tylko wywołuje, czy przywołuje potężne zdarzenie, ale też $\mathrm{n}$ a d a j e te

${ }^{14}$ Berberova, dz.cyt. , s. 191. 
$\mathrm{m} \mathrm{u}$ w y d a r z e n i u postać. (...) Słowo mityczne decyduje poprzez upostaciowanie, nie zabija, tak jak abstrahujące od życia pojęcie, lecz w y w oł u j e $\dot{z}$ y c i e; znajduje się w najostrzejszej, jaką tylko można sobie wyobrazić, sprzeczności z teorią.". ${ }^{15}$

Wszystkie podkreślone przez mnie właściwości mitycznej narracji znajdują swoje odzwierciedlenie u Muratowa. Tak rozumiana mityczność Obrazów Włoch sprawia, że stają się one świętą księgą dla wszystkich tych, którzy myślą o podróży włoskiej, „biblią" entuzjastów włoskiej przygody. Użyty tu cudzysłów sugeruje by nie mieszać porządków i nie mylić księgi Muratowa z prawdziwym księgami świętymi; nie pozbawia jej to wszakże kreacyjnych mocy i siły oddziaływania im właściwym. Widać przy tym wyraźnie, że tego rodzaju sposób zapisu rzeczywistości nie był przypadkiem, przeciwnie: podyktowany był świadomym zamysłem autora. Jakim - o tym za chwilę.

\section{3.}

Pierwsza, dwutomowa edycja arcydzieła Muratowa, ukazała się po raz pierwszy w 1atach 1911-12. Wydanie drugie - trzytomowe - opublikowane zostało w Berlinie w roku 1924. W stosunku do pierwszego wydania uzupełnione zostało jeszcze o dwa istotne rozdziały: Od Tybru do Arna - obejmujący podróż po Umbrii i północnych Włoszech i melancholijny Epilog, który zamyka książkę kompozycyjnie, ale jest także szczególnie istotny dla zrozumienia strategii ideowej książki. Kilka fragmentów z ostatniego rozdziału książki dobrze odsłania jego głębokie - w istocie: radykalnie anty-turystyczne - rozumienie jego włoskiej przygody. Pokazują one dowodnie, że - odmiennie niż w przewodnikowych opowieściach - tu w ogóle nie chodzi o ekscytację włoskimi pięknościami: obojętnie czy należącymi do świata sztuki, czy natury. Prawdziwy skarb ukryty jest głębiej. Muratow pisze otwartym tekstem o tym szczególnym nie porównywalnym $\mathrm{z}$ niczym innym włoskim doświadczeniu. Pisze, że z pewnością są kraje bardziej od Włoch niezwykłe, że istnieją bardziej porywające pejzaże, że są cywilizacje starsze i bardziej nobliwe. Ale tylko we Włoszech mamy naoczne doświadczenie pełni istnienia:

„Włochy nie są ani tragicznym czy sentymentalnym teatrem, ani księgą wspomnień, ani źródłem egzotycznych doznań, lecz ojczystym domem naszej duszy, żywą stronicą naszego życia, rytmem naszego serca bijącego mocniej na widok rzeczy zarówno wielkich, jak i małych; oto czym są Włochy, i pod tym względem nic się z nimi nie może równać. Ani ich krajobrazy, ani cuda ich sztuki nie oślepiają nas i nie ogłuszają. Nikogo nie przytłaczają i w niczym nie kłócą się z wewnętrzną istotą człowieka współczesnego. Ani przez chwilę nie odczuwamy ich obcości, ów świat, na który tu patrzymy, choć zdumiewający, nie jest ani cudzy, ani w sobie zamknięty". ${ }^{16}$

15 G. van der Leeuw, Fenomenologia religii, przeł. J. Prokopiuk, Warszawa 1997, s. 362-363, podkr. DC.

${ }_{16}$ Muratow, dz. cyt., t. 2, , s.369. 
Niezwykle charakterystyczne jest to, że odwrotnie do przewodnikowych narracji w których, zgodnie z konwencją, poleca się tylko to, co jaskrawo wystaje ponad przeciętność - w swoim pisaniu Muratow jest także piewcą zwykłości, zwyczajności. Oprócz spodziewanych ekstaz będących udziałem historyka sztuki spotkamy tu akapity, w których do głosu dochodzi mało efektowna codzienność:

„We Włoszech wszystko jest dla nas ważne i cenne. Ten sam rytm rządzi płaskorzeźbami Donatella i wieczornym ruchem florenckiej ulicy. Dzwony bijące na Ave Maria rozbrzmiewają zarówno w złotym malowidle starego mistrza sieneńskiego, jak wśród blasków słońca, które dziś zachodzi nad wieżami San Gimignano. Ta sama triumfalna nuta rozbrzmiewa $\mathrm{w}$ genialnych dziełach Palladia i w wyrobach pierwszego lepszego włoskiego rzemieślnika. Cała gama kolorów Tycjana ma ten sam winny smak, tę samą chłodną słodycz, co żółte grona, z których tłoczą z lekka pienistą valpolicellę". ${ }^{17}$

Jeszcze raz obserwować możemy zabieg przemiany czasowego, historycznego, zmiennego, przygodnego w uogólnioną formułę mitycznego obrazu. W harmonijną konstrukcję odporną na upływ czasu. W elegijnym zakończeniu książki spotykamy też wyraźnie sformułowaną eksplikację celu włoskich wędrówek. Zwraca w tym akapicie uwagę wyraźnie wypunktowany motyw inicjacyjny, motyw przemiany wewnętrznej:

„Słowa: podróż do Włoch - są wiele mówiące, obejmują bowiem nasze doświadczenie, nasze życie we włoskim żywiole, wyzwolenie nowych sił duchowych, narodziny nowych zdolności, zwiększenie skali naszych pragnień. Dokonując się w czasie i w przestrzeni, owa podróż prowadzi także przez głębie naszej istoty i zakreśla na dnie naszej duszy swój oślepiający krąg. Wracamy z Włoch z poczuciem spoistości przyczyn i skutków, jednolitości dziejów przeszłych i obecnych, nierozerwalnych związków jednostki i świata, prawdy wiecznego kołowrotu wszechrzeczy, dawniejszej niż uboga myśl o ciągłym postępie". ${ }^{18}$

To jest ta sama myśl, którą kilkadziesiąt lat później w nieco innych słowach wyrazi wprost i bez niedomówień Josif Brodski. W rozmowie Solomonem Wołkowem wydobywa on subtelną - acz fundamentalną - różnicę między rajską utopią a rajskim projektem:

„Wołkow: Dziś być może, da się traktować Italię jako raj na ziemi, bo dla ciebie to, mówiąc krótko, muzeum. Ale wiesz: wszystkie te piękne malowidła, kościoły, cały ten marmur i tak dalej - wszystko to powstawało w trakcie niekończących się wojen, cierpień, krwawego horroru.

Brodski: Nie, to jest raj nie dla nas. I nie dzisiaj. Czemu więc mówię o Italii, że to naprawdę jedyne miejsce, godne miana raju na ziemi? Otóż dlatego, że mieszkając tam, rozumiem, jaki winien być porządek świata, prawda?"19

17 Muratow, dz.cyt., t. 2, s. 369.

${ }_{18}$ Muratow, dz. cyt., t. 2, s. 370.

19 S. Wołkow, Świat poety. Rozmowy z Josifem Brodskim, przeł. J. Gondowicz, Warszawa 2001, s. 218. 
Rozpisana na wiele stron i rozdziałów książka Muratowa przynosi tę samą rewelatorska myśl, tyle że wspartą dziesiątkami empirycznych przykładów.

\section{4.}

Jeszcze raz więc: czym są Obrazy Włoch Pawła Muratowa? Czym jest ta wspaniała i szczodra księga i o czym przede wszystkim jest? Ustaliliśmy, że z pewnością nie jest to przewodnik po miejscach atrakcyjnych do zwiedzania. Ale też, dodajmy, nie jest to tylko zbiór kompetentnych uwagi historyka sztuki o obrazach (czasami nietrafnych w interpretacjach ${ }^{20}$ ) i architekturze, albo tom zajmujących zapisków uważnego podróżnika. Nie w tym tkwi wielkość tej mitycznej księgi. Nie jest to także, jak chcieliby niektórzy, opowieść o ziemskim raju, ani arkadyjski miraż estetycznego spełnienia. Czym w takim razie jest?

Wspomniałem, że drugie wydanie Obrazów Włoch kończy się weneckim epilogiem. To emblematyczne miejsce pożegnania Muratowa z włoską rzeczywistością: od przekroczenia „letejskich wód” weneckiej laguny rozpoczyna się przecież cała książka, i Wenecja okazuje się także kompozycyjną klamrą spinającą całą opowieść. Ale równie ważne jak miejsce jest tu doświadczenie czasu. Jest rok 1914: „Z okien małego albergo włoskiego na Riva degli Schiavoni przez kilka dni i nocy widziałem parowiec, który miał niebawem odpłynąć do Pireusu i Konstantynopola. W skwarne letnie wieczory ‘Torino’ wabił ku sobie płonącymi w jego wnętrzu białymi elektrycznymi światłami. (...) Po płycie szerokiego nabrzeża przebiegli już gazeciarze, głosząc wieść o zabójstwie arcyksięcia. Różnoplemienni bywalcy Floriana i Quadriego wymienili już spojrzenia, w których zabłysły pierwsze iskry wrogości przyszłych strasznych lat. Wielu z nich ogarnęły złe przeczucia. W owe os tatn i e s p ok o j n e dni Europy niektórzy po raz pierwszy oglądali tchnącą wiecznym zamyśleniem Wenecję, która później znów im się pojawi w chwili śmierci lub w długich latach cierpienia". ${ }^{21}$

To zakończenie coś nam powinno przypomnieć. Tak kończy się przecież Czarodziejska góra, inna wielka księga napisana w tym samym czasie. W gorzkim finale powieści Manna zatytułowanym Grom, który jest strukturalnym odpowiednikiem Epilogu Muratowa, czytamy: „zagrzmiał dobrze nam znany grom, ogłuszająca detonacja nagromadzonej od dawna złowróżbnej mieszaniny otępienia i rozdrażnienia - mówiąc z pewnym respektem, historyczny grom, który wstrząsnął podstawami ziemi”. I dalej: „nastąpił zamach na księcia, bojowe hasło dla wszystkich, prócz niemieckich śpiochów, wyraźny znak dla świadomych głów, do których słusznie możemy zaliczyć pana Settembriniego". 22

${ }^{20}$ Przykładem fascynująca, ale oparta na wątłych przesłankach interpretacja alegorycznego obrazu Belliniego z Uffiziów. Dziś wiemy więcej na temat tego obrazu i jego ideowych źródeł, por. S. J. Delaney, The Iconography of Giovanni Bellini's Sacred Allegory, The Art Bulletin, Vol. 59, No. 3 (Sep., 1977), s. 331-335.

${ }_{21}$ Muratow, $d z$. cyt., t. 2, s. 368, podkr. DC.

22 T. Mann, Czarodziejska góra, przeł. J. Łukowski, Warszawa 1972, t. 2, s. 527, 529. 
Siedmioletni pobyt Castorpa w sanatorium dobiegł końca, za chwilę spotkamy go już na froncie, $\mathrm{z}$ bagnetem $\mathrm{w}$ ręku, leżącego na ubłoconej ziemi...

Doprawdy, dziwna koincydencja: nawet daty wydania obydwu książek się zgadzają! Mann publikuje swoje opus w roku 1924, dokładnie w tym czasie, kiedy wychodzi pełna berlińska edycja Obrazów Włoch. Rzecz jasna, podobieństwo obydwu wielkich narracji nie sprowadza się do dat wydania. Tu idzie o istotne filiacje i to na kilku poziomach równocześnie. Najpierw poetyka. Księga Muratowa to esej pisany przez wrażliwego historyka sztuki, który fragmentami czytany być może jak najlepsza, wysmakowana stylistycznie proza; z kolei powieść Manna to nominalnie powieść, ale partie eseistyczne stanowią jej ważną część. Przemieszanie literatury (jakże) pięknej i dyskursu, fabularnych przygód i erudycyjnie podbitego eseju to ich wspólne cechy wyróżniające. Obydwie książki to także dwa różne - ale w pewnych punktach bliskie sobie - traktaty o czasie. Muratow jest historykiem niezwykle wrażliwym na upływ czasu, w swojej książce rejestruje różne rytmy czasowe, zapisuje zmienność objawiającą się w architekturze „nowych" Włoch, ale zastanawia się także nad trwałością arcydzieł sztuki, wskazuje na ich niepodległość wobec chronologii. Powieść Manna, nazywana zwyczajowo wielką księgą o czasie ${ }^{23}$, jest sporządzonym w języku figuralnym finezyjnym rozważaniem o jego doświadczaniu, o różnych typach czasu, o paradoksach czasu i jego tajemniczej naturze; w swoich rozpoznaniach to narracja bliska wielkim dziełom filozoficznym (od Augustyna pod Heideggera). Linearność czasu i kolistość czasu, rozciągliwość czasu i jego kompresja, dialektyka chwili i wieczności - to istotne tematy obydwu dzieł, choć rozegrane - by tak rzec - w innej scenerii i pośród innych bohaterów. Uderzające podobieństwa zachodzą też w planie intelektualnym. Obrazy Włoch i Czarodziejska góra to przy wszystkich oczywistych różnicach dwa wielkie dzieła o duchowym genotypie kultury zachodniej. Muratow widzi go przez pryzmat włoskiej historii i sztuki, Mann - poprzez spór o kształt nowoczesnego humanizmu; swoją odpowiedź rozpina pomiędzy tyradami Settembriniego i Naphty, walczących o duszę niewinnego Castorpa. Wreszcie: obydwa dzieła mają wyraźnie inicjacyjną strukturę. Obrazy Włoch wprowadzają adepta do ogrodu sztuk, pokazując mu najciekawsze okazy, ale też nie pomijając mniej efektownej codzienności. Czarodziejska góra, kontynuując tradycje niemieckiej Entwicklungsroman, odsłania stopniowe dojrzewanie bohatera (ale i czytelnika), jego przejście od potocznego doświadczania świata do poziomów subtelniejszej natury.

Wszystko to dowodzi ponad chyba wszelką wątpliwość, że właściwe miejsce Obrazów Włoch nie jest na półce z włoskimi bedekerami, ale obok największych literackich (i intelektualnych) dzieł swojego czasu! Dopiero w wyniku tego przesunięcia będziemy w stanie docenić ich wielkość, dopiero wtedy zrozumiemy dlaczego ta księga nie jest

${ }^{23}$ Finezyjną analizę różnych czasu, ale także retoryki czasu w Czarodziejskiej górze przeprowadza Ricoeur, por. P. Ricoeur, Czas i opowieść. Konfiguracja w opowieści fikcyjnej, przeł. J. Jakubowski, Kraków 2008, t. 2, s. 36-51. 
zwykłym świadectwem historycznym, której wartość ma wymiar zaledwie muzealny, a przede wszystkim dowiemy się dlaczego - mimo tylu zakrętów historii - jego spokojne promieniowanie dochodzi do nas wciąż z oddali.

Muratow kończy swoją baśń włoską na chwilę przed potopem, w momencie fundamentalnego wydarzenia, które odkreśli radykalnie wiek XIX od XX. Doskonale zdaje sobie sprawę (podobnie jak Mann) z jego przełomowego charakteru, rozumie, że kultura europejska jest $\mathrm{w}$ trakcie bezprecedensowego przesilenia, że nic nie będzie już takie, jak kiedyś. I rzeczywiście: wybuch I wojny otwiera tamę bestialstwom wieku XX, jest świadectwem nie mającego precedensu kryzysu wartości, który niedługo później zaowocuje ekscesami dwóch totalitaryzmów. Jeden z nich, sowiecki bolszewizm, pozbawi Muratowa ojczyzny. W roku 1922, wraz z innymi znakomitymi przedstawicielami „srebrnego wieku”, będzie zmuszony opuścić Rosję. Dołączy do licznego grona emigrantów, ludzi wydziedziczonych, wyrzuconych z własnego domu w wyniku ideologicznego zaślepienia. Umiera w Irlandii w roku 1950, odsunięty na boczny tor, całkowicie zapomniany.

Obrazy Włoch, nie znane, nie czytane w świecie, przez niemal pół wieku dostępne są tylko w języku oryginału; tłumaczenie arcyksięgi na egzotyczny język polski w niczym nie poprawia jego sytuacji. Można zrozumieć, dlaczego Muratow pisze o Włoszech jako greckiej oikouménē, a w pojęciu tym dostrzec można nie tylko ideę świata oswojonego, zamieszkanego, ale także myśl o domu (oikos). Bo też Obrazy Włoch, to w gruncie rzeczy namiętna opowieść o domu, w znaczeniu dalece wykraczającym poza wąsko pragmatyczne jego rozumienie. Dokładniej może: o poszukiwaniu domu, o pragnieniu domu, o powrocie do domu. $\mathrm{O}$ z a m i e s z k i w a n i u, w którego tle pobrzmiewa budowanie i myślenie, w pogłębionej lekcji tych terminów pozostawionej nam przez Heideggera. Dziś rozumiemy to może jeszcze lepiej, bo historia XX wieku mocno naznaczona jest piętnem wykorzenienia, uchodźstwa, emigracji i bezdomności.

Dopiero wtedy, kiedy uwzględni się te fakty i spojrzy na dokonanie rosyjskiego historyka sztuki à vol d’oiseau, można w pełni docenić wagę i wielkość Obrazów Włoch. Ta książka, obok swojej faktograficznej zawartości, obok bogactwa opisów i obserwacji, mówi chyba przede wszystkim o dwóch dopełniających kwestiach: pamięci i sztuce. Po pierwsze, pokazuje, że kultura, która chce być żywa i twórcza musi być pamięcią, aktywną pamięcią, że nie przypadkiem eskalacja barbarii rozpoczyna się zwykle od amputacji pamięci. Po drugie, że esencją kultury są te zjawiska, które w swej osnowie są bytami duchowej natury. Sztuka przede wszystkim. Co prawda, wielka sztuka nie jest w stanie zapobiec cywilizacyjnym nieszczęściom, ale jest najcenniejszym depozytem, jakim dysponujemy. Pokazuje nam nasze duchowe maksimum, uwrażliwia na to, co w istnieniu nie jest „nasze”, ludzkie. W swoim rdzeniu jest rzeczywistością odporną na działanie czasu.

W tym kontekście jeszcze większej wagi nabiera niezwykłe spostrzeżenie Clive’a Jamesa: „niesamowite, wręcz dojmujące jest to, że Muratow przemawiał autorytatywnym tonem, który wydaje się dobiegać do nas z przyszłości raczej, a nie z przeszłości, tak jak 
gdyby jego testament, opublikowany na wygnaniu, był zwiastunem czasów, w których proces dewastacji, charakteryzujący historię współczesną, ulegnie odwróceniu”. ${ }^{4}$ Prorocza księga Muratowa wchodzi z nami w żywy rezonans, rozpoznajemy się w niej, a ona wciąż nas czyta. To jest nasz wiatyk na czas przesilenia kultury, na czas niepewności i wieszczonego od lat kolejnego „przewartościowania wszystkich wartości”...

${ }^{24}$ James, dz. cyt., s. 527. 